\title{
上顎洞にみられた腺房細胞腫症例
}

\author{
藤原 啓次・田端 敏秀
}

\section{Acinic Cell Tumor of Maxillary Sinus}

\author{
Keiji Fujihara and Toshihide Tabata \\ (Wakayama Medical College)
}

An 80-year-old woman with a tumor of the soft palate visited our clinic. She had scratched the tumor often with her finger nail. Two years later, her right cheek became swollen, and the soft palate tumor increased in size.

$\mathrm{X}$-ray films and CT scans revealed that the tumor was located in the maxillary sinus and palate. The contour was well defined. The maxillary tumor occupied the anterior portion of the right maxillary sinus, with bony destruction.

The tumor was successfully removed under general anesthesia. Histological examination confirmed that the tumor consisted mainly of serous-type cells containing numerous basophilic granules in the cytoplasm, which were PAS-positive with diastase resistance and negative for mucicarmine staining. Ultrastructurally, the tumor cells generally consisted of large cells with abundant electron-dense granules. It was concluded that this tumor was an acinic cell tumor.

Tumor recurrence was noted two years after surgical removal. A second operation was not performed, because the tumor was slow-growing and because of her age.

Key words: acinic cell tumor, tumor of maxillary sinus, TEM

\section{はじめに}

腺房細胞腫瘍 (acinic cell tumor) は，耳下腺 や顎下腺の漿液細胞に類似した比較的異形の少 ない円形または多角円形細胞からなる腫瘍で， 耳下腺に好発する ${ }^{1}$. 本腫瘍には悪性に経過し た症例も報告され，腺房細胞癌 (acinic cell carcinoma）の名が広く使用されていた。しかし， 大部分は良性に経過する2) ことから，WHO の 分類では腺房細胞腫の名称を採用している。本 腫瘍の発生率は唾液腺腫瘍の $1 \sim 3 \%$ と低く, 大部分は耳下腺より発生し, 小唾液腺由来の屯 のは非常に稀れである。

今回，われわれは上䫟洞ならびに軟口蓋に発
生した症例を経験したので, 若干の文献的考察 を加えて報告する。

\section{症例}

患者 : 80歳, 女性.

初診：昭和61年 2 月 10 日.

既往歴 : 50歳より慢性副鼻腔炎にて近医耳鼻 科にて鼻処置を受けていた５2歳に乳癌にて根 治術を受けていた。

現病歴 : 昭和58年頃より軟口蓋の腫瘤に気付 き, 手指にて $2 \sim 3$ 回切除を繰り返していた. 昭和60年 8 月頃より右鼻翼部の膨瘤に気付き, 同年10月, 日高病院を受診し, 軟口蓋腫瘤と右 上歯肉部の膨瘤及び，頭部 CT にて右上顎洞か 
ら硬口蓋にかけて骨破壊を伴う腫瘍陰影を指摘 される．軟口蓋腫瘤より生検を行い，組織診断 は多形性腺腫之判明し当科紹介となる。

現症：右煩部から右鼻翼部にかけて膨隆が認 められたが，圧痛はなかった（図1)。又，軟 口蓋の右側部に $2.5 \times 2.5 \mathrm{~cm}$ 大の腫瘤が認め られた (図 2 a). 同腫瘍は表面は乳頭状で弾 性軟であった，右歯肉部に屯表面整で弾性軟の 腫瘤が認められた（図 2 b).

CT 所見：上顎洞の前壁之内側壁侅破壊を

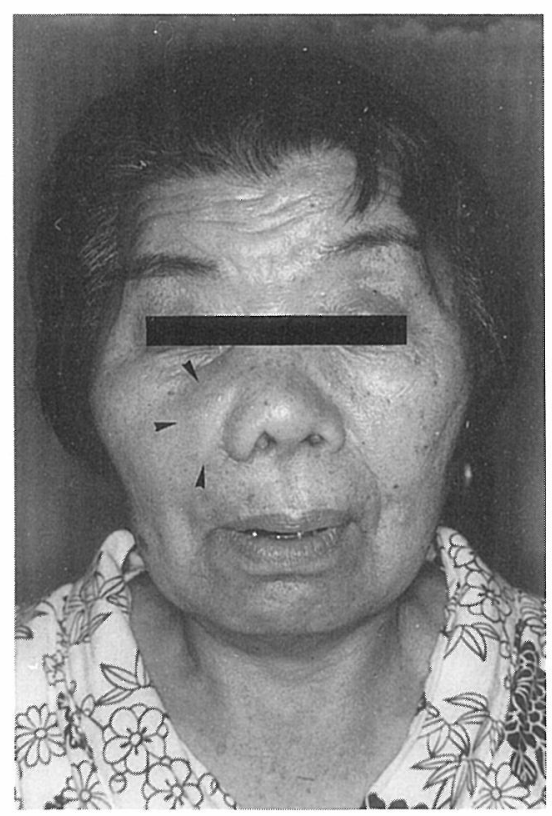

図 1 右鼻翼部に膨隆を認める.

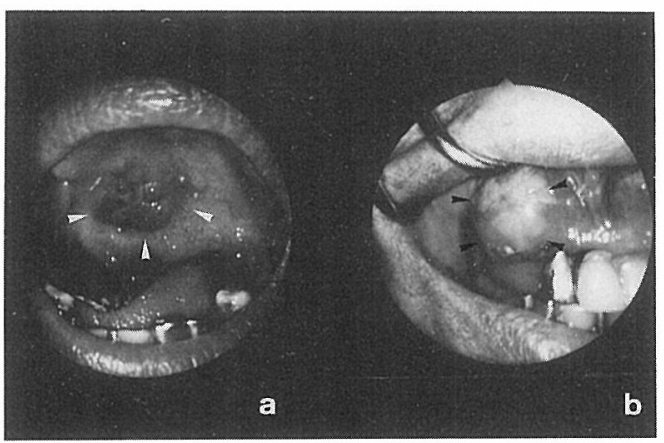

a ：軟口蓋腫瘤

$\mathrm{b}$ ：歯肉部の腫瘤

図 2
伴い（図 3 a ）歯肉部まで及ぶ腫瘍陰影が認め られた (図 3 b).

$\mathrm{Ga}$ シンチ：異常集積像は認められなかった。 臨床検查所見：特に異常所見はなかった。

手術および経過：昭和61年 3 月18日全身麻酔 下に腫瘤の摘出術を行った。軟口蓋腫瘤は周囲 の結合織を含めて容易に摘出された。 上顎洞は 前壁, 内側壁, 梨状孔縁まで骨破壊が認められ たが，腫溜は線維性被膜で覆われ周国組織之は 隔てられており，周囲の結合織を含めて摘出し た，尚，再腫瘤間に直接の連絡は認めなかった，

摘出物の肉眼的所見: 軟口盍腫瘤 $(2.5 \times 2.5$ $\times 1.5 \mathrm{~cm}$, 図 $4 \mathrm{a})$ と上顎洞腫瘤 $(4 \times 3 \times 3 \mathrm{~cm}$, 図 4 b) は線維性被膜に包まれ，割面は灰白色 でやや赤みがかっており，ところどころ出血巣 あ認められた。

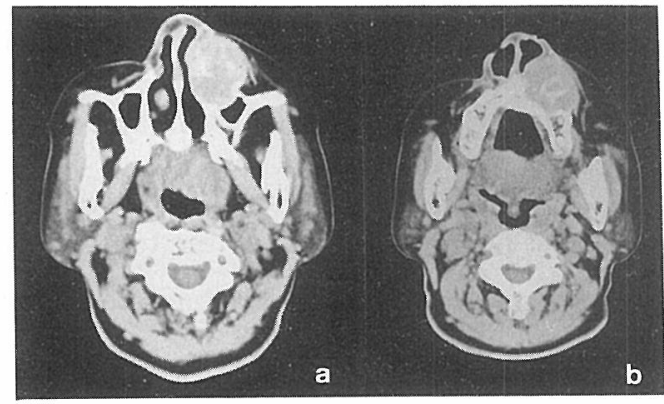

$\mathrm{a}$ ：上顎部

b ：彩翼部

図 3 初湸時の C T 像

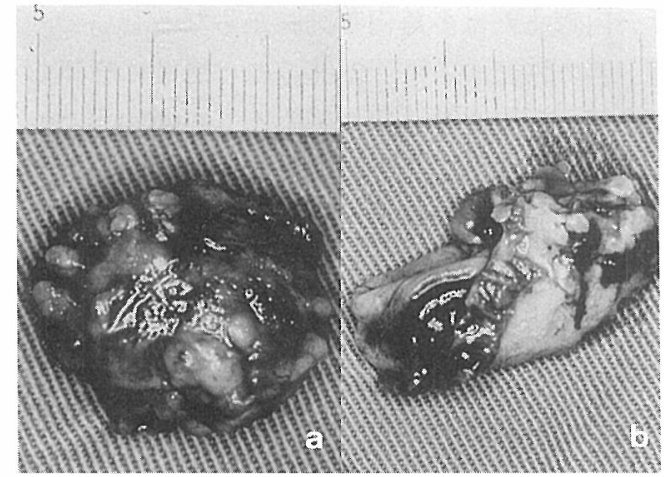

a：軟口蓋腫瘵

$\mathrm{b}$ ：上顎洞腫瘤

闵 4 摘出組織 
病理学的所見：腫瘍実質は浆液性腺房細胞に 類似した単調な増殖を示す腫瘍細胞からなる。 間質成分はそしく，その間質はほとんど毛細血 管に占められていた。腫瘍細胞はその毛細血管 により小胞栄あるいは索状様に分けられていた。 両腫瘍は骨破壞像を示している線維組織によっ て境され，かつ周囲との境界む比較的明瞭であ った，軟口蓋腫瘍では血管へ浸潤する所見屯認 められた。腫瘍細胞は大型の多面形あるいは円 形で，円形の小型の核は基底側に偏在するが， 異型性を示すものは認めなかった（図 $5 a$, b )。細胞質は好塩基性の分泌顆粒を有してい た。細胞質の顆粒は PAS 陽性物質でアミラー ゼに消化されず（図 6 a)，粘液染色では陰性 を示した（図6 b).

病理組織学的診断: 腺房細胞腫.

電子顕微鏡所見：腫瘍細胞は比較的大きな細

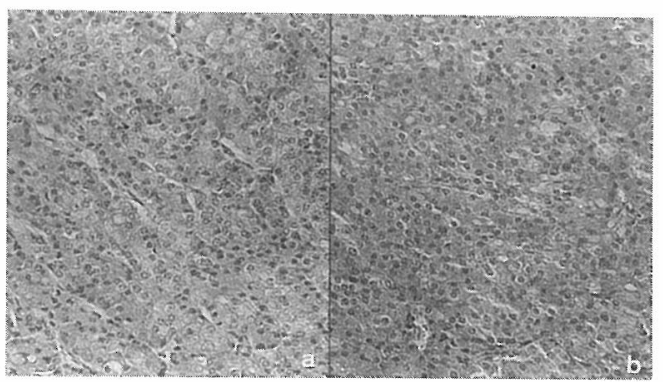

図 5

a：軟口蓋腫瘤の組織像 $(\times 100)$

$\mathrm{b} ：$ 上顎洞腫瘤の組織像 $(\times 100)$

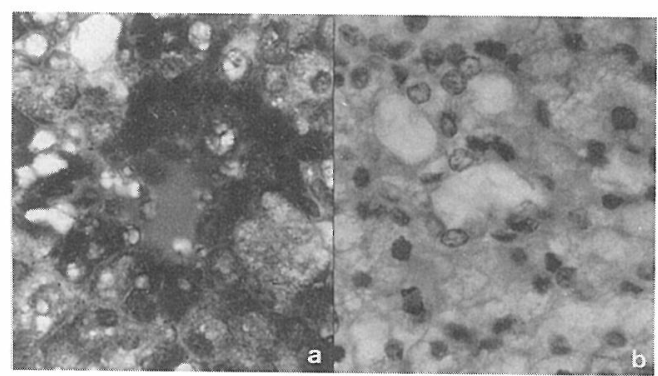

図 6

$\mathrm{a} ＼mathrm{~ ： 軟 口 蓋 腫 瘤 の ~ P ~ A ~ S ~ 染 色 像 （ × 200 ） ~}$

b : 軟口蓋腫瘤の粘液染色像 $\quad(\times 200)$
胞で，類円形ないし不正形の偏在した核を有し， 種々の電子密度を示す分泌顆粒を有していた。 細胞の辺縁部には発達した粗面小胞体やゴルジ 装置が認められた（図 7)。

\section{考案}

腺房細胞腫の多くは疼痛はなく，成長が遅く， 被包されており，良性唾液腺腫瘍とよく似た臨 床所見を呈する ${ }^{(1) 34}$. 組織学的にも，良性の像 を呈するものが，ほとんどである4が，その中 にも悪性の報告があり ${ }^{1)}, \mathrm{Abrams}^{5)}$ は18\%の症 例に周囲組織への浸潤像をみ，肉眼的飞被膜を 認めた23例中，顕微鏡的に実際に被包されてい る像を認めたのは 5 例にすぎなかったと述べ， 腫瘍の被膜の有無が予後に関係するといわれて (いる ${ }^{4) 5}$. 以上のように本腫瘍は悪性の潜在能 を有する低悪性度癌と理解されている11.

好発部位は耳下腺であり，小唾液腺には稀で

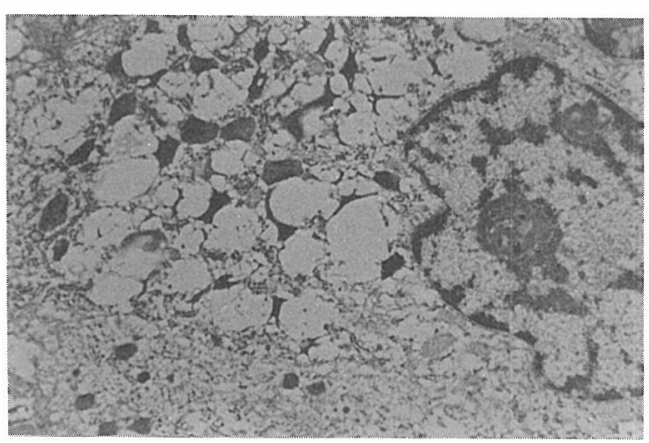

図 7 軟口蓋腫瘤の電顕像 $(\times 2500)$

表 1 小唾液腺由来の腺房細胞腫瘍 一報告例一

\begin{tabular}{|c|c|c|}
\hline 部 位 & 症例数 & (\%) \\
\hline 口蓝 & 16 & $(51.6)$ \\
\hline 類 粘 膜 & 4 & $(12.9)$ \\
\hline 臼 後 部 & 3 & (9.7) \\
\hline 舌 & 2 & (6.5) \\
\hline 歯 肉 & 2 & (6.5) \\
\hline 下ロ唇 & 1 & (3.2) \\
\hline 鼻副鼾腔 & 2 & $(6.5)$ \\
\hline 上咽 頭 & 1 & (3.2) \\
\hline 計 & 31 & \\
\hline
\end{tabular}


ある．著者らが検索しえた小唾液腺由来の腺房 細胞腫は31例で，口蓋16，煩部 4， 臼後部 3， 舌 2 , 上歯肉 2 , 下口唇 1 , 鼻副鼻腔 2 , 上咽 頭 1 であった（表 1 ）。頭頸部領域では口腔内 粘膜はもちろんであるが，咽頭や気道粘膜にも

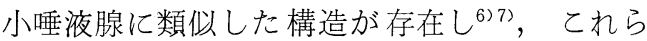
はすべて付属器腺と呼ばれる腺構造である。多 数の小唾液腺腫瘍を検討した報告をみると，頭 頸部管腔のすべての部位にわたって各種の唾液 腺型腫瘍が分布しているととがわかる ${ }^{6)}$. 鼻副 鼻腔に発生した症例は非常に少なく，Spiro は 鼻腔に ${ }^{8)} ，$ David は上顎洞に原発した腺房細胞 腫を発表している ${ }^{9)}$. 本症例の場合，軟口蓋と 上顎洞の腫瘍の間には直接の連絡は認められず, 軟口蓋腫瘍に血管への浸潤像が認められたとと， 上顎洞腫瘍が遅れて認められたととから上顎洞 腫瘍は軟口蓋腫瘍が転移したものと考えた。好 発年齢は $40 〜 60$ 歳代で，男女差はなかった ${ }^{13)}$.

組織学的には本腫瘍は一般には間質に乏しく, しかもその間質のほとんどが血管よりなるとさ れている( ${ }^{4)}$. $\mathrm{Abrams}^{5)}$ らは全症例中 $2 / 3$ 亿多数 の血管を認め，出血が特徵的であったと述べて いる．本症例に拈いても腫瘍細胞が毛細血管に より小胞巣あるいは索状様に分けられていた。 これは本腫瘍に特徵的な所見と考えられる。腫 瘍実質は漿液性腺房細胞に類似した単調な増殖 を示す腫瘍細胞からなる，細胞の胞体は大きく その境界は比較的明瞭で，核分裂は少なく，小 さな核が一端に位置し，核の配列により腺房構 造を思わせる，特殊染色をした場合，腺房細胞 腫瘍の細胞内顆粒は, Abrams ら ${ }^{5}$ によれば，よ く分化した腺房細胞腫瘍は PAS 反応に強く陽 性を示し，粘液染色はほとんど陰性，分化の程 度の低い例では PAS 反応は弱く, 粘液反応は 強いといっている。本症例は PAS 反応陽性で 粘液反応陰性であり，上く分化した典型的な腺 房細胞腫瘍であるといえる。

電顕的には，本腫瘍には分泌顆粒を有する漿 液性腺房細胞類似の細胞之分泌顆粒を欠く介在 部導管上皮様の細胞がみられるという(10) 12).
本症例では漿液性腺房細胞に類似した細胞が主 であった。

腺房細胞腫の予後について Abrams ら ${ }^{5)}$ は, 72 例中局所再発が 6 例 $(8 \%$ ) 所属リンパ節転 移が 4 例 (5.5\%)，遠隔転移が 2 例 ( $3 \%)$,

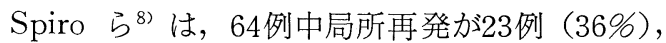
所属リンパ節転移が10 例 (16\%)，遠隔転移が 8 例 (12\%), Eneroth 弓 ${ }^{13}$ は，37例中局所再発 が11例 (30\%)，所属リンパ節転移が 4 例(11\%)， 遠隔転移が 5 例（13\%）に認められた之記載し ている， 5 年生存率について，Thoma ${ }^{14)}$ は90 \%, Eneroth ${ }^{13)}$ は89\%であるが，20年生存率は $56 \%$ にずないと発表している。 そして，再発 は一般に遅く，数年から十数年後に現れるあの が多いとされている(13)15) 17). 治療についてで あるが，以前は腫瘍摘出術で十分であるとされ ていた。しかし，再発，転移はまれではなく， 放射線治療がほとんど効を奏しない(4) 17) ととも あって腫瘤を摘出するだけでなく，広い範囲に わたる徹底的な外科的処置が必要とされてい る ${ }^{4)}$ 13) 16) 18) 211). さて，本症例のように術後の 病理診断で悪性が確定した場合，追加処置が問 題になる。村上ら ${ }^{222}$ は腺房細胞腫などのように 悪性度が低い腫瘍では，十分切除できたと思わ れる場合には，一応このままにして経過観察す ることにし，切除縁がかなり接近していた場合 には，再手術を行うとしている．本症例では腫 瘍摘出時に，腫瘍周囲の結合組織を含め大きく 切除できたあのとして，経過観察を行った。し かし，術後 2 年で右歯肉部に再発を認めた。現 在年齢を考慮して再手術は行わず経過観察中で ある。

\section{結語}

80歳女性の軟口蓋部と右上顎洞に発生した骨 破壊を伴う腺房細胞腫瘍を経験した．組織学的 所見から両部の腫瘍は高分化型の腺房細胞腫瘍 と診断した．周囲組織を含めた切除術を行った が，手術後 2 年で右歯肉部に再発を認めた。現 在年齢を考慮して経過観察中である。 


\section{引用文献}

1 ）清見原正騎，石川武憲，三次正春，他：穿刺吸引 細胞診の術前診断で判明した煩腺由来腺房細胞腫 の 1 例. 日臨細胞誌 $25: 726 〜 730 ， 1986$.

2 ) 副島 渉, 田中 夫, 後藤昌昭, 他 : 耳下腺に発 生した腺房細胞腫の 1 例. 日口外誌 $30 ： 498$ 503, 1984.

3 ) 石川梧朗 : 口腔病理学 【. 改訂版. 745 748頁, 永末書店，京都，1982。

4 ）江崎民夫，加藤裕生，吉田正彦，他：小唾液腺腺 房細胞癌の 1 例. 癌の臨床 $20: 553 \sim 560,1974$.

5 ) Abrams AM, Cornryn J, Scofield $\mathrm{HH}$, et al : Acinic cell adenocarcinoma of the major salivary glands. Cancer 18 : 1145 1162, 1965.

6）小川 明, 竹田千里, 熟津邦雄, 他：上咽頭腺房 細胞癌の 1 例. 耳喉 $48 ： 993 \sim 998 ， 1976$.

7 ) Ranger D, Thackray AC and Lucas RB : Mucous gland tumors. Brit J Cancer $10: 1 \sim 16$, 1956.

8) Spiro RH, Koss LG, Hajdn SI, et al : Tumors of minor salivary origin; a clinicopathological study of 492 cases. Cancer $31: 117 \sim 129,1973$.

9) Manace ED and Goldman JL : Acinic cell carcinoma of the paranasal sinuses. Laryngoscope $81: 1074 \sim 1082,1971$.

10）谷 慶明，小池正夫，小守 明，他：頓粘膜に生 じた腺房細胞腫の 1 例. 日口外誌 $31: 296 \sim 300$, 1985.

11) Erlandson RA and Tandler B : Ultrastructure of acinic cell carcinoma of parotid gland. Arch Path $93: 130 \sim 140,1972$.

12) Kay $\mathrm{S}$ and Schatzki PF : Ultrastructure of acinic cell carcinoma of the parotid salivary gland. Cancer 29 : 235 240, 1972.
13) Eneroth CM, Jacobson PA and Blanck C : Acinic cell carcinoma of the parotid gland. Cancer 19 : 1761 1772, 1966.

14) Thoma KH, Gorlin RJ and Goldman HM : Thomas Oral Pathology, 6th ed. pp 1024 1036, CV Mosby Co, St Louis, 1970.

15) Evance RW, Cruickshank $\mathrm{AH}$ and McDougall $\mathrm{C}$ : Epithelial tumors of the salivary glands. pp 98 119, WB Saunders Co, Philaderphia, London, Tronto, 1970.

16）西尾克彦, 広瀬義明：唾液腺疾患の臨床的考察. 信州医誌 $16: 742 \sim 756,1967$.

17) Feyrter $\mathrm{F}:$ Uber das glykogenreiche retikulierte Adenom der Speicheldrusen. Zeitschrift. Krebsforschung $65:$ 446 454, 1963.

18) Fox NM, ReMine MH and Woolner LB : Acinic cell carcinoma of the major salivary glands. Am J Surg $106: 860 \sim 867,1963$.

19) Grage TB and Lober PH : Malignant tumors of the major salivary glands. Surgery $52: 284 \sim$ 294, 1962.

20) Grage TB, Lober PH and Arthlger SW : Acinic cell carcinoma of the parotid gland. Amer J Surg 102 : 765 768, 1961.

21) Rivlin RS : Acinic cell adenocarcinoma of the parotid gland. Am J Surg $100: 639 \sim 642,1960$.

22）村上 泰, 猪 忠彦, 堀内正敏, 他 : 耳下腺腫瘍 70症例の治療経験. 耳喉 $48: 589 \sim 602,1976$.

$\left.\begin{array}{l}\text { 原稿受付 : 平成元年 } 2 \text { 月 } 21 \text { 日 } \\ \text { 原稿採択 : 平成元年 } 6 \text { 月 } 20 \text { 日 } \\ \text { 別刷請求先 : 藤原啓次 } \\ \text { Ү } 640 \text { 和歌山市七番丁 } 27 \\ \text { 和歌山県立医科大学耳鼻咽喉科学教室 }\end{array}\right)$

